\title{
Northern European Prehistory, From Below
}

Charlotte DAmm \& JAnNe SAARIKIVI (eds): Networks, Interaction and Emerging Identities in Fennoscandia and Beyond. Papers from the conference held in Tromsø, Norway, October 13-16, 2009. Suomalais-Ugrilaisen Seuran Toimituksia 265. Helsinki: SuomalaisUgrilainen Seura 2012.

The bulk of the articles contained in the present volume are ethnographical and archaeological case studies which base themselves on theoretical notions such as social networks and interaction, rather than fixed concepts of ethnicity and identity. In terms of geographical scope, the articles range from Alaska to Japan, but a large number of them focus on various aspects of Saami history. In terms of time depth, many of the articles concern themselves with the time of colonialization and contacts between hunter-gatherer populations and emerging states. This collection of articles is based on the 2009 conference in Tromsø mentioned in the title, which itself was the conclusion of a research project, Early network- ing in Northern Fennoscandia, based at the Centre for Advanced Studies in Oslo in 2008-2009. The articles are divided into two parts: the first, ... and beyond, focusing on wider contexts than that of northern Fennoscandia, the second, Northern Fennoscandia, focusing on the area defined by the research project.

In the introductory chapter (VIIXIII), Charlotte Damm and Janne Saarikivi introduce the research project that lay at the basis of this collection, defining its focus as lying on hunter-fisher-gatherer societies of the north and their interaction with farmer societies and emerging states to the south. In terms of theoretical orientation, they express criticism towards projecting established ethnic and linguistic identities back to prehistoric times, and instead propose orienting towards a more basic level of analysis in terms of social networks. This theoretical framework is worked out in more detail in Damm's as well as Saarikivi and Lavento's articles later in the volume, and is indeed manifest in the vast majority of the articles. 
The first paper, Alaskan analogues and eastern uncertainties: Reconstructing Thule Inuit interaction networks in the Eastern North American Arctic by T. Max Friesen (3-26), deals with the society of the Classic Thule Period (approx. 1300-1500) in the far northeast of North America. This society was characterized by a coastal economy based on the hunting of large marine mammals such as bowhead whales, a "delayed-return" economy which means that resources (such as the aforementioned large marine mammals) were acquired in large quantities at the same time and then stored for later use, and a great deal of complexity and variety in settlement types, means of transport, etc. (4-5). What we don't know about the Classic Thule society are issues such as the extent of social differentiation, conflict and warfare (both within Classic Thule society and with outside groups), demographics and size of settlements, etc. (5-6). To find an answer to such questions, Max Friesen proposes looking for an analogical model among contemporary societies of the North American Arctic, and settles on that of the Inupiat of North-western Alaska, which is described in detail (8-10). An important contrast between NW Alaskan society and that of the Classic Thule period is that NW Alaskan society is the product of centuries of development, in which boundaries and territorial divisions were highly consolidated, whereas Classic Thule society was the result of the settlement of "new lands". This could mean that in Classic Thule, regional boundaries were more unstable, interregional interaction and partnerships more intense, and relations with outsider groups (Dorset culture Palaeo-Eskimos, Norse settlers, Algonquians) more unsettled (13-14). Whereas Max Friesen finds that evidence for trade in highstatus goods suggests that Classic Thule society was socially differentiated like that of NW Alaska (17), we cannot say anything about the location of specific regional groups (15), the role of warfare (18), or indeed trade in bulk goods and the presence of trade fairs (18). It is furthermore not only so that evidence for trade in bulk goods, trade fairs, and warfare is missing, but that the archaeological record indicates that these phenomena were absent (20). This leads Max Friesen to caution about the role of analogical reasoning in ethnography (21).

In the second paper, From hunter to herder? Investigating the spread of transport innovations in Northwest Siberia (27-48), Peter Jordan investigates the adoption of reindeer among the Khanty of the upper 
tributaries of the Ob River, specifically those of the Iugan basin. Jordan sketches the contrast between reindeer herding in the northern tundra, with vast herds used for meat and other materials, and that of the boreal forests, with smallerscale herding for transportation purposes (28). The integration of reindeer into the hunting and fishing economies of the forest zones, such as that of the Iugan basin Khanty, raises questions: in order to protect reindeer against mosquitoes, for example, the location of summer sites needs to be adapted to the needs of the reindeer, meaning that reindeer bring significant costs as well as potential benefits (40). Why, then, did the Iugan basin Khanty import reindeer? Notably, they were imported from the northern tundra, rather than bred locally (31). One possible answer is that pressure from Russian colonialization and more intense taxation forced the Khanty to change their lifestyle, either by developing a more settled culture based on commercial fishing, or by intensifying fur-hunting with a greater geographical range, with the help of reindeer for transportation. Jordan rejects this explanation: the tendency towards more dispersed settlement among the Iugan basin Khanty and the intensification of fur-hunting long preceded the in- troduction of reindeer in the 19th century (33-34). Instead, a spate of forest fires and a shortage of local woodland and game in the 19th century may have forced the Khanty to adopt the reindeer in order to increase mobility and hunting range (35). However, this adoption was only partially successful: in some smaller communities, the labour costs associated with reindeer herding proved too great, and reindeer herding was subsequently abandoned. With this idea, the article exemplifies how the adoption of new technology is not always advantageous: it may bring along a range of practical problems that may prove unsurmountable (40).

The third paper, Navigating huntergatherer resilience: networks and insularity in the prehistory of the Ryukyu Islands (49-66) by Mark J. Hudson, Mami Aoyama and Kara C. Hoover, differs from the previous both in scope (which ranges over several millennia) and geographical location - the Ryukyu islands are subtropical rather than subarctic. The authors base themselves on the concept of resilience: the amount of stress a system such as a society can undergo from outside influences (such as natural catastrophes or climate change) and still remain intact (50-51). Their research question is to what extent the specific circum- 
stances of small islands, with, for example, generally low biodiversity but the presence of endemic species found nowhere else, affected the resilience of local hunter-gatherer societies (50-52). The islands studied fall into two groups: the Amami and Okinawa islands in the north, and the Sakishima islands to the south. The Amami and Okinawa islands show a pottery culture from about 9000 BP, with apparent links to the Jōmon culture of Kyushu to the north - though in little else than pottery (53-54). The Sakishima islands, on the other hand, bear no evidence of any northern links and may well have been first settled from Taiwan or Southeast Asia (55). An important difference is that while settlement on the Amami and Okinawa islands endured constantly, human settlements on the Sakishima islands died out twice - first in approx. $3500 \mathrm{BP}$ with new settlement arriving from possibly the Philippines after a hiatus of about 8 oo years, and for the second time at the end of the first millennium $\mathrm{AD}$ (56-57). To answer the question of why human society on the Sakishima islands collapsed twice, but that of Okinawa and Amami remained, the authors argue that the role of trade networks such as that in shell trade needs to be more thoroughly researched. Isolation in the absence of trade networks leaves an island society more vulnerable to social collapse, but the presence of trade networks may bring along epidemic diseases and the possibility of exploitative social relations (57). Furthermore, periodic tsunamis may have contributed to the collapse of the earliest prehistoric culture in Sakishima (58). The relevance of studies such as these for the challenges posed to huntergatherer populations by environmental change is obvious and made explicit by the authors (49-50).

Robert Jarvenpa's and Hetty Jo Brumback's paper The ChipewyanCree-Métis Interaction Sphere and the Fur Trade Political Economy: Archaeological, Ethnohistorical and Ethnographic Approaches (67-92) studies the interrelationship of Chipewyan, Cree and Métis Cree, and Euro-Canadian groups during the expansion of the fur trade in central subarctic Canada in the late 19th century. During this time, some Chipewyan groups moved southwards in the lower Churchill River basin and came under the dominance of local Cree groups (67-70), while a Métis Cree labourer class emerged with the expansion and commercialization of the fur trade (74). The result was a tripartite economic system based on Chipewyan and Cree hunters (as well as, to some extent, white trap- 
pers), a Métis labourer class whose life revolved around trade posts, and a Euro-Canadian managerial class (74). The authors hypothesize that during this period, the biogeographical niches available to Chipewyan and Cree huntergatherer groups expanded, and that economic specialization, integration into the main political economy and contacts with the Euro-Canadian community are indexed by a greater intake of imported, rather than local food. Furthermore, they postulate that interethnic relationships, traditionally rather hostile between the Chipewyan and Cree, became gradually more cooperative, and that a kind of socioeconomic stratification emerged (74). These hypotheses are investigated through historical archaeology (e.g. studying the remains of canned, rather than locally produced food), archival ethnohistory and ethnography (77). The results are that some expansion of biogeographical niches is evident for Chipewyan groups, but not Cree (84-85), and that in terms of food consumption, a strong contrast emerged between Chipewyan hunters on the one hand, who remained reliant on locally produced food, and Métis labourers as well as white trappers on the other, who were dependent on imported food $(79,85)$. In terms of dwelling size, a contrast emerged between relatively large Chipewyan dwellings, smaller Cree dwellings, and the smallest dwellings for Euro-Canadian trappers: this is related to familial relationships. With the Chipewyan, a recently married daughter would, with her husband, live for a while with her parents. Furthermore, Cree and Métis Cree may have had more external storage space, making for smaller dwelling houses. The dwellings of white trappers were the smallest, as these were usually bachelors only living in the area for some years. (8o). Whereas the authors find that a kind of socioeconomic stratification definitely emerged, with Cree and Métis Cree dominant over the Chipewyan hunters, relationships did not necessarily become less adversarial: while some cooperation between Chipewyan and Cree emerged in terms of shared festivals and the like, the Chipewyan remained notably leery of the perceived magico-medicinal powers of the Cree (85). Jarvenpa and Brumback's study is a good example of the complex and changing relations between various indigenous groups under the influence of colonialization and western settlement.

Pekka Sammallahti's article, Bottlenecks and contacts in the linguistic prehistory of the Saami (93-104) stands out in two ways. For the 
first, the prehistory of the Saami is sketched with a very, very broad brush - starting with the development of modern man. Second, the connection to theoretical models of networks and interactivity apparent in the other articles is absent here. Sammallahti starts out by considering the development of human language, and the presence of language-like capabilities among animals such as the African Grey Parrot and hominid species such as the Neanderthals (93-94). On the basis of what Sammallahti considers to be a very slow pace of cultural evolution among the $\mathrm{Ne}$ anderthals, he argues that their linguistic capabilities were restricted in comparison to those of modern man, more specifically, the Neanderthals are argued to have lacked the capabilities to express epistemic modalities (93-95). As for possible linguistic contacts between Neanderthals and modern man, Sammallahti believes their respective linguistic capabilities to have been too far apart to allow for the transfer of linguistic elements.

There are two problems with this reasoning. First of all, work on Neanderthal genetics by researchers such as Svante Pääbo appears indicate that interbreeding occurred between Neanderthals and modern humans, as well as between modern humans and the slightly more dis- tant Denisovan sub-species. These results are tentative but have been widely reported, and should have been mentioned in this context. Adding to this the earlier discovery of what may be intermediary or hybrid Neanderthal-modern forms, e.g. the Lagar Velho child (Owens 2006), there is a prima facie case for assuming that modern humans and Neanderthals were able to communicate with each other and therefore had broadly similar linguistic capabilities. More speculatively, there have been suggestions that modern man interbred with remnant populations of homo erectus as well (Whitfield 2008), presupposing, of course, that there was an temporal overlap of modern man and homo erectus in, for example, Southeast Asia. This is, of course, highly uncertain, but there is a possibility that future views of the ancestry of modern humans may resemble a bush with intertwined branches rather than a straightforward family tree, in other words, that the linear Out-of-Africa model and the older multiregional model of human origins may be reconciled in some manner. In this light, to argue that no linguistic contact between Neanderthals and modern humans was possible, or that $\mathrm{Ne}$ anderthals lacked the capabilities to express epistemic modalities, seems extremely rash. 
The second problem lies with the notion of slow Neanderthal cultural evolution vs. quick evolution of modern man. The main cultural "revolution" in the history of early man is the Aurignacian period of approx. 47-41,000 BP, usually associated with the advent of Cro-Magnon man in Europe. The Aurignacian introduced finer tools, figurative art in the form of Venus figurines and others, spectacular cave paintings, and traces of spiritual life and religion. Though there are earlier indications of the use of decorative art among early modern humans, such as the use of shells for necklaces in Southern Africa (Cartmill and Smith 2009: 415), art of this kind is present among Neanderthals too (Choi 2010). The Aurignacian revolution, however, cannot be coterminous with the emergence of modern language. In light of the fact that modern humans settled Australia at the latest in Aurignacian times and possibly much earlier, and that there is no evidence for more primitive linguistic states in Australia or indeed anywhere else, modern language must have developed earlier, and quite possibly at the same time as the origin of anatomically modern humans at $200 k \mathrm{BP}$, thus very long before the Aurignacian.

I have addressed these two points at length in order to indicate that of the time between the origin of human language, which has a reasonable terminus ante quem at the spread of modern humans out of Africa around 1ook BP, but may well lie much further back during archaic homo sapiens or even homo erectus periods, and the last six millennia or so which are within reach of historical linguistics, there is very little we can say. Certainly, there is no basis for such notions as that the Neanderthals lacked the capabilities for epistemic modalities - the very little we actually can, tentatively, say, speaks against this.

This note of caution also applies to part of the remainder of Sammallahti's article. After describing a "bottleneck" in the prehistory of European populations in the shape of the last Ice Age, when human habitation was confined to a small number of habitable zones or refugia (95-96), Sammallahti pinpoints the Swiderian culture of modern-day Poland as the point of origin of Pre-Uralic languages, which then spread to the broad zone between the Baltics and the Ural mountains (98). The Swiderian culture, however, is dated at the end of the Palaeolithic, some lok years BP; Proto-Uralic is, in Kallio's hypothesis (2006: 16-17), associated with the archaeological culture of the Sejma-Turbino phenomenon approx. 4000 years 
BP. This leaves six thousand years of possible diffusions and migrations, which may or may not be reflected in the archaeological record (which, like the linguistic records, degrades over time). The warnings levelled by Damm and Saarikivi later in this volume against identifying archaeological cultures and ethnolinguistic groups apply all the more strongly here. It should be noted that the Sejma-Turbino phenomenon is given an eastern origin by E. N. Chernykh in the next article of this volume (117), and that this position is indeed widely held, though not uncontroversial (Kallio 2006: 17, footnote).

Sammallahti provides an interesting discussion of the later linguistic contacts of Saami, including the unknown substratum convincingly demonstrated by Aikio (2004, 2013). Sammallahti argues that some lexical items belonging to this substratum are shared with Western Indo-European languages, and that they may represent a pre-IndoEuropean language (99). That is entirely possible, though the possibility that they instead represent some form of Indo-European or perhaps a later intrusive non-Indo-European speech should be taken into consideration as well. The language in question may well have still been spoken in northern Scandinavia in the middle of the first millennium
$\mathrm{AD}$, and the expansion of Indo-European languages into north-western Europe took place as much as three to four millennia earlier.

At the end of the article, Sammallahti makes the interesting point that the poor quality of the Saami language in the first printed Saami books, from 1619, may represent a pidgin language, and that it may represent the oldest documentation of a pidgin (103). But surely that honour should go to the Romance-based lingua franca pidgin of the Mediterranean, which has been documented since late medieval times.

The following paper, The northern hunters, fishers and gatherers and their southern neighbours in Eurasia in the Early Metal Age (105-122) by E. N. Chernykh, concludes the first part of the volume, ... and beyond. It provides a broad overview of the cultural development of nomadic pastoralism in the Eurasian steppe region, and its role in the spread of metallurgy. The time periods of relevance are the ProtoMetal Age, when rare and primitive copper artefacts make their appearance but no real metallurgy yet exists, and the Early Metal Age, when copper mining and copper metallurgy take off in the Danube area and the Carpathian basin around the ${ }^{\text {th }}$ millennium BC. This is also 
the time when nomadic pastoral cultures emerge in the steppe area. (105). Notably, copper metallurgy appears to have developed independently among the hunter-fisher-gatherer cultures living north of the Eurasian Steppe Belt (ESB) in the 4th millennium BC (107-108). The ESB and the nomadic pastoralists inhabiting it must have played a great role in the transition to the Late Bronze Age at the turn of the 3rd and 2nd millennia BC, when metal-working was spread to the east of Asia. Chernykh argues that all subsequent innovations, from the development of iron to that of firearms, remained broadly within the zone defined by this expansion, up until the emergence of modern states and colonialization. (110). Chernykh's discussion of the Sejma-Turbino phenomenon - a network of armed traders which spread excellent-quality bronze artefacts across Northern Eurasia which Chernykh argues had an eastern origin, is of particular interest to Uralists because of the hypothesis that the Sejma-Turbino phenomenon may be connected with the spread of Uralic languages. (114-117).

The second part of the collection, Northern Fennoscandia, opens with Charlotte Damm's article Interaction within and between col- lectives: networking in Northern Fennoscandia (125-138), which sets out some of the theoretical considerations at the basis of the papers included in this volume. Cautioning that a critical stance towards established identities should not be confused with holding such identities to be illusory and non-existent (125), Damm describes her theoretical notions as collectives, based on shared social or cultural elements or on technological and economic practices, identities, collectives of people who are aware of their shared position in society, communities of practice, which are collectives based on shared technological or economic practice which may or may not share a particular identity, and networks as the set of relations within any of the three aforementioned (125). Damm mentions that hitherto, archaeological cultures have been all too often defined as assemblages of tools such as pottery with specific decorations, and that instead, one should look at the usage and production of tools such as pottery and see to what extent various kinds of collectives may be based thereupon (127). Thus, the theoretical terms introduced by Damm serve as an intermediary between the material remains of an archaeological culture and the people (with an assumed specific language and ethnicity) be- 
hind them. As an example, Damm takes up Early Northern Comb Ware pottery. Pottery production cannot simply be copied: it must be learned. Assuming that women were the main producers of pottery, Damm hypothesizes that the spread of this pottery style through Finland could have been the work of women migrating north to settle there, or by women from the north who would travel south to learn the pottery craft before returning home. (132-133). Pottery is contrasted with amber artefacts, which may be transmitted between collectives without the knowledge of their production. The spread of amber artefacts is thought to be based on gift-giving or partnership rituals between collectives or individuals holding a special position within their collective (133-135). Damm's article is of great interest to researchers of prehistoric times as it introduces theoretical concepts that may help us avoid all too simplistic identifications of archaeological cultures and ethnolinguistic entities.

Fredrik Hallgren's article, A permeable border - long-distance contacts between hunters and farmers in the Early Neolithic of Scandinavia (139154) deals with contacts between the Funnel Beaker Culture of Early Neolithic Scandinavia (400o-
3300 BC) and their hunter-fishergatherer neighbours to the north, named the Slate Culture (139). Both cultures are characterized by Hallgren as "locally performed practices of non-local repertoires" (142); the Funnel Beaker Culture, for instance, shared some features, such as battle axes, with wider regions, but Funnel Beaker battle axes nonetheless showed specific regional designs, and the same goes for the slate tools of the Slate Culture (140-142). A point of departure for describing interaction between the two cultures is the find of a slate knife in a site for ritual depositions at the Funnel Beaker site of Skogsmossen in Central Sweden (140). The knife has a design which suggests an origin from western Scandinavia or the modern-day Norwegian coast, but the specific type of slate is thought to originate from the eastern side of the Scandinavian mountain range (143-145), suggesting interesting regional links in the production and distribution of slate tools. More items of this kind are found on both sides of the divide - Funnel Beaker axes can be found in Slate Culture areas, and flint axes from Scania have been found at Skogsmossen (146-149). All of this indicates wide-ranging social networks across the whole of Scandinavia, and furthermore, bidirectional relations between 
early farmers and hunter-gatherers which were not, as previously often thought, asymmetrical, with the hunter-gatherers as the passive, submissive party (151).

In the following article, Change and recollection: house structures and social identification in Finnmark, Arctic Norway 2400 BC - AD 300 (155176), Marianne Skandfer deals with the role of memory and remembered history in the formation of Saami identity as expressed through the reuse of a dwelling type called the Gressbakken house in Finnmark. These semi-subterranean houses have an appearance of being highly organized and symmetric, and it has therefore been suggested that their first appearance in the third millennium BC was a result of managing social stress in the Saami community caused by the development of new technology, expansion of trade networks and resulting social stratification (157-158). However, the symmetry and uniformity of Gressbakken dwellings may have been overestimated in earlier literature (160-161). Interestingly, after having been vacated for about a millennium, Gressbakken sites were taken into use again at around 300 BC (161-162). Skandfer argues that this reuse was a way for the emergent Saami to reconnect with a, perhaps mythologized, past at a time of change and discontinuity, and of the emergence of a specific Saami identity (167-170). This thesis is inherently plausible and interesting, as it pays proper due to the more ideal motivations that may have guided the behaviour of prehistoric populations, instead of confining explanations to economic, technological or social change. This said, the explanation as presented in this article remains abductive in nature, and would need further argument.

Janne Saarikivi's and Mika Lavento's paper, Linguistics and Archaeology: a critical view of an interdisciplinary approach with reference to the prehistory of northern Scandinavia $(177-216)$ is one of the longer in this volume and of great interest to historical linguists. Synthetic views of human prehistory, which combine the results of historical linguistics (reconstructed proto-languages) and those of archaeology (archaeological cultures), have often been based on one-to-one correspondences between presumed ethnolinguistic entities and archaeological cultures, such as the identification between the Battle Axe culture and a north-western branch of ProtoIndo-European, that between Proto-Uralic and the Sejma-Turbino phenomenon, etc. Saarikivi and Lavento express scepticism towards the validity of such synthetic 
views, and instead argue for a more detailed, bottom-up approach in which the spread of particular artefacts or the toponymy of a given area is explained with the help of both archaeology and linguistics. (178-179). After a detailed report on the methodology of historical linguistics, Saarikivi and Lavento remark that there is a basic lack of correspondence between the research objects of linguistics and archaeology: “(...) historical linguistics is mainly about the history of languages and the units that they contain (words, phonemes, etc.), not about the history of speech communities. Archaeology, in turn, is about artefacts, technologies, raw materials, communities and networks, not about historical sociolinguistics." (181).

A remark should be made here: this is true, in practice, but it need not necessarily be so. There is a lack of metascientific precision, so to speak, in historical linguistics, as the discipline encompasses both abstract objects (phonemes, grammars) and concrete, historical events which embody such abstract objects (the linguistic behaviour of speech communities throughout history), and these are not always precisely distinguished. Strictly speaking, phonemes and grammars have no history. The speech events in which these are imma- nent, however, do. There have been recent attempts to orient historical linguistics towards a kind of history of speech events, by, for example, Croft (2000) and Mufwene (2001). These attempts are very much open to criticism (De Smit 2010: 3-5) but they do indicate that it may be possible to work out a model in which the research object of historical linguistics is a spatiotemporally extended network of speech events. Such a model would orient historical linguistics closer to the history of speech communities and at least solve part of the lack of equivalence that Saarikivi and Lavento point out.

Saarikivi and Lavento outline some areas in which linguistic and archaeological results may nonetheless converge: evidence from reconstructed vocabulary, toponymic evidence, and the circumstance that the borders of linguistic areas may often coincide with ecologically defined areas (181-184). A serious problem, nonetheless, is that speech communities may often have been multilingual in prehistoric times (as they are in historic times), and that this multilingualism is not necessarily reflected in the archaeological record (neither are language contact phenomena or language shifts) (182, 190-191). As examples, Saarikivi and Lavento mention that the ancestors of 
the Saami at some point shifted towards Saami from a hitherto unknown language, but that their cultural traditions continued unbroken (191-192). Ethnicity itself does not correspond with language in a predictable and uniform fashion (193), and markers of ethnicity such as specific dress are often poorly reflected in the archaeological record (197). Basically, speech communities show internal diversity and internal dynamics that are not necessarily reflected in the archaeological record at all, which makes one-to-one identifications between ethnolinguistic entities and archaeological cultures an extremely hazardous affair.

I find myself in broad agreement with these points, with two caveats. For the first, Saarikivi and Lavento stress that "Both migrations and language shifts cause the expansions and relocations of language areas and it seems to be the case that the latter process is, most likely, the more important one, at least in the Eurasian context." (191). This I find to be a hazardous assumption. True, the romantic notion of prehistoric peoples as roving and conquering bands of warriors already containing within themselves the seeds of the Germans, Englishmen and Finns they would later become is, of course, simplistic. At the same time, our earliest historical records are full of what appear to be migrating tribes of people displacing and sometimes exterminating other tribes on their way - from the Dorian Greeks and the Sea Peoples in the chaotic twilight of the Bronze Age to the great migrations at the end of the Roman empire, with many examples in between as well. The Anglo-Saxon settlement of eastern England, for example, shows little traces of continuity: Celtic influence on Old English appears to be very restricted (Schrijver 2014: 18-22), but there is also discontinuity in cultural domains such as religion, architecture, etc. One may of course argue that the migration period is highly historically specific. However, great civilizations had been emerging and collapsing in the Mediterranean and Near East for millennia.

Second, speech communities may well have been often multilingual, but not necessarily in a symmetric way. Usually, one language (which is not necessarily the language of local élites) would be used for intergroup communication, and the more coherent an archaeological culture - the more likely that the artefacts, technology, economy which characterize that archaeological culture necessitates social networks of communication - the more likely the assump- 
tion of at least a common lingua franca. The Battle Axe culture, for instance, may have represented a variety of more or less closely related Indo-European languages or dialects, and perhaps even have involved some non-Indo-European ones, but this does not mean that the notion that it spread a language that could be characterized, in broad terms, as Northwest IndoEuropean is thereby invalid.

Saarikivi and Lavento work out an alternative model on which correlations between archaeology and language can be made on three levels: location (a site in archaeological terms, a toponym or cluster of toponyms in linguistic terms), community (a cluster of sites or an ecological zone in archaeological terms, a speech community in linguistic terms) and network (a type of material technology in archaeological terms, the spread of vocabulary in linguistic terms) (201). This entails that the equivalent of an archaeological culture in terms of technology would be the trajectories of borrowed vocabulary, rather than linguistic areas. In other words, what corresponds to archaeological cultures would be Sprachbunds of languages in mutual contact. (202).

As testified by my comments above, I agree with the basic thrust but not necessarily the extent of
Saarikivi and Lavento's criticism. Their efforts not to satisfy themselves with mere criticism but to work out a specific alternative model are nothing less than laudable, however. The article should be compulsory reading for anyone with an interest in prehistoric languages and cultures.

In his article Networks, diversity and mobility among the Northern Sámi in the 16th century (217-239), Lars Ivar Hansen asks to what extent various Saami networks in northern Finnmark were dependent on imported goods, and to what extent they paid their taxes with self-produced goods, and inquires about the role of mobility among these Saami groups (217). His source material consists of taxation records, which have been well-preserved particularly on the Swedish side (221). Notably, Swedish taxation was individual and not based on households, which makes these records uninformative in establishing household numbers, but very useful in tracking the movements of individual Saami men (224). His results with regard to the first question is that the Saami society of the Varanger fjord appears to have been heavily commercialized: almost all taxes were paid with imported goods. The products of hunting, fishing and trapping must 
have been locally consumed or traded, and are not at all reflected in taxation records (226). A counterposed situation is visible with the Saami of Anár, who paid their taxes almost wholly with locally produced furs and dried pike, with only some money, and then only Swedish money (suggesting trade contacts with Sweden only) emerging late in the records. Altafjord and the inland sites show a mixed picture, and evidence of trade with the Norwegian and Danish side as well. (228). Trade networks thus appear to have been strongest in coastal areas (229). Mobility is studied in the Altafjord area only. In more eastern areas, the methods of tax collection, focusing on specific sites during specific gatherings such as markets, mean that they are useless for tracing mobility patterns (229-230). Ivar Hansen distinguishes three kinds of mobility: seasonal mobility, permanent resettling, and intermittent settling at various places for intervals of, for example, a few years. Seasonal mobility is found to occur in a direction from inland areas to the coast in summer, obviously connected with work at salmon fisheries (230). Permanent resettling happened mainly along rivers and between adjacent fords (231-232), whereas interval stays are most common in the earlier periods covered by the records, less later - which Ivar Hansen argues to be related to a recession in trade contacts with the Danish and Norwegian side, and a development of sedentary lifestyles revolving around animal husbandry (233-236). Ivar Hansen's article provides a nice example of the volume's orientation towards networks and detailed case studies, and the discussion of the usefulness of tax records in pinpointing historical trade networks and mobility patterns is especially interesting.

Jukka Korpela's paper Migratory Lapps and the population explosion of eastern Finns: the early modern colonization of Eastern Finland reconsidered (241-261) likewise includes interesting discussions of the reliability - or, in this case, unreliability - of source material. According to the traditional account of medieval Eastern Finland, it was inhabited by some migratory Lapps (signifying Saami but also other Finno-Ugric hunter-fishergatherers), while agriculturalists from the south and west would visit the area for hunting, fishing and small-scale cultivation during the summer. After the beginning of the 16th century, however, a population boom occurred in the area. (241-242). Korpela raises a series of issues with this account. For 
example, connections through waterways between Eastern Finland and the south and the west would be very difficult, and population estimates from medieval times unreliable. (242-245.) Instead, Korpela suggests, "Lapps" as forest hunter-fisher-gatherers would be largely invisible to medieval records, which focused on settled farmers under the control of local lords (247-248). The reformation, and the turn towards the vernacular, enabled a much more effective local administration, and the "population explosion" is rather the result of a large number of forest dwellers previously unaccounted for suddenly becoming of interest to local authorities (252-253). The integration of forest hunter-fishergatherers into the administration of the emerging state is sketched on the basis of Russian records: Lapps first come to the attention of record-keepers when they settle and start paying taxes; next, they receive Christian names but are still recorded as "Lapps"; finally, they are wholly integrated into the main economy and the moniker "Lapp" is no longer used. (251.)

Dikka Storm's article A network of missionaries and the establishment of knowledge: Creating space (263-283) applies Doreen Massey's conception of space to the research of missionary activities among the Saami of Northern Norway in the 18th century. Massey's conception of space is that it is relational - it is the result of interrelations through interactions between subjects; that it is processual rather than readymade; and that it is inherently heterogenous and pluralistic (265). This conception is then applied to a detailed study of missionary activities among the Saami, focusing on key figures such as the missionaries Thomas von Westen (1687-1727), Isak Olsen (168o-1730), Jens Kildahl (1683-1767) and Kildahl's wife, the native Saami Karen Arnesdatter, as well as their professional and personal relationships. Attention is given to the organization and transmission of knowledge through missionary activities (271-), the role of missionaries in addressing social injustices and developing education (268-270) and, notably, the role of missionaries' wives such as Karen Arnesdatter, who is argued to have played an important role in disseminating information about Saami culture, the old Saami religion, etc. (278-). The study is highly interesting, rich in detail, and, like other articles in this volume, focuses on the encounter of indigenous populations and emerging states during the period of colonialism. It is not entirely clear to me, however, 
to what extent Massey's theoretical framework contributes to the high-quality historical research exhibited here.

Finally, Lars-Gunnar Larsson's article Variation in Ume Saami: the role of vocabulary in dialect descriptions (285-298) is linguistic in scope, though it fits well with the theoretical framework of this volume in focusing on internal variation and internal relationships of the Ume Saami speech community. Research on this variation and these relationships has been impeded, as Larsson (289-290) remarks, by the fact that the main handbook on Ume Saami, Schlachter's (1958) grammar and dictionary, excellent as it is, focuses on a single idiolect. By taking into account archival material as well, Larsson analyses aspects of the dialect subgrouping and borders of Ume Saami with special reference to lexical criteria in addition to the phonological and morphological criteria which have hitherto been mainly used in Saami dialectology (288-289). Larsson finds a high degree of lexical convergence in the forest zones of the Ume Saami area, which meshes well with phonological evidence and suggests a forest dialect in Ume Saami (293-294). Interestingly, lexical statistics show some lexical convergence between this forest dialect and the mountain Saami of Northern Tärna as well, which may be attributed to the fact that the winter grazing grounds of the Northern Tärna mountain Saami lie in the vicinity of Ume Saami forest villages (294-295). In this way, the volume's focus on the relations that underlie identities rather than those identities themselves shows itself to be relevant to linguistic research as well.

As a whole, the volume contains a collection of excellent case studies characterized by a focus on the social networks and relations that constitute ethnic and linguistic identities, instead of taking the latter type of identities for granted. The ideas advanced in, for example, Saarikivi and Lavento's as well as Damm's more theoretical articles, but also in case studies such as Skandfer's focus on "ideal" categories such as memory and the construction of socially shared memory, are of great interest to archaeologists and historical linguists alike. For Uralists specifically, this volume is valuable in at least the following three ways. Many of the individual studies focus on aspects of Saami history and prehistory. Second, the subtle, somewhat deconstructionist but by no means reductionist approach to ethnicity and language adopted 
here is of great interest to future attempts to synthesize the results of archaeology and linguistics in prehistorical research on the Uralic and Indo-European languages and their speakers. Third, many articles, such as Jarvenpa's and Brumbach's, Korpela's and Storm's focus on the encounter between hunterfisher-gatherer peoples and emerging states during the period of early modernity and colonialism, the ways in which hunters-fisher-gatherers were either adopted into the expanding economy or marginalized by it, and the ways in which new social relations and social stratifications emerged between various ethnic groups. This knowledge is of obvious relevance to the research of, and protection of, circumpolar minority languages and peoples today.

\section{Merlijn de Smit}

\section{Literature}

Aikio, A. 2004: An essay on substrate studies and the origin of Saami. I. Hyvärinen, P. Kallio \& J. Korhonen (eds): Etymologie, Entlehnungen und Entwicklungen. Festschrift für Jorma Koivulehto zum 7o. Geburtstag. Mémoires de la Société Néophilologique de Helsinki 63. Helsinki: Société Néophilologique. 5-34.

- 2013: An essay on Saami linguistic prehistory. - R. Grünthal \& P. Kallio (eds): A linguistic map of prehistoric
Northern Europe. Suomalais-Ugrilaisen Seuran Toimituksia 266. Helsinki: Suomalais-Ugrilainen Seura. 63-117.

Cartmill, M. \& F. H. Smith 2009: The human lineage. Hoboken: WileyBlackwell.

Chol, C. Q. 2010: Heavy brows, high art? Newly unearthed painted shells show Neandertals were Homo Sapiens' mental equals. - Scientific American 8.1.2010.

$<$ http://www.scientificamerican.com/ article/neandertal-art-human/>.

CROFT, W. 2000: Explaining language change: an evolutionary approach. Harlow: Pearson.

De Smit, M. 2010: Modelling mixed languages: some remarks on the case of Old Helsinki Slang. - Journal of Language Contact 3: 1-19.

Kallio, P. 2006: Suomen kantakielten absoluuttista kronologiaa. - Virittäjä: 2-25.

Mufwene, S. 2001: The ecology of language evolution. Cambridge: Cambridge University Press.

Owen, J. 2006: Neandertals, Modern Humans interbred, bone study suggests. - National Geographic News 30.10.2006. $<$ http://news.nationalgeographic.com/news/2006/10/061030neanderthals.html>.

SCHLACHTER, W. 1958: Wörterbuch des Waldlappendialekts von Malå und Texte zur Ethnographie. Helsinki: Suomalais-Ugrilainen Seura.

SChrijver, P. 2014: Language contact and the origins of the Germanic languages. New York: Routledge.

Whitfield, J. 2008: Lovers, not fighters? New genetic signs that modern humans mated with Homo Erectus. - Scientific American 4.2.2008. $<$ http://www.scientificamerican. com/article/lovers-not-fighters/ $>$. 